\title{
BMJ Global Health Community-level spillover effects of an intervention to prevent intimate partner violence and HIV transmission in rural Ethiopia
}

\author{
Jessica Leight (D) , ${ }^{1}$ Negussie Deyessa (D) , ${ }^{2}$ Fabio Verani, ${ }^{3}$ Samuel Tewolde, ${ }^{4}$ \\ Vandana Sharma (i) ${ }^{5}$
}

To cite: Leight J, Deyessa N, Verani F, et al. Communitylevel spillover effects of an intervention to prevent intimate partner violence and HIV transmission in rural Ethiopia. BMJ Global Health 2021;6:e004075. doi:10.1136/ bmjgh-2020-004075

Handling editor Seye Abimbola

- Additional material is published online only. To view, please visit the journal online (http://dx.doi.org/10.1136/ bmjgh-2020-004075).

Received 28 September 2020 Revised 14 December 2020 Accepted 16 December 2020

Check for updates

\section{(c) Author(s) (or their} employer(s)) 2021. Re-use permitted under CC BY-NC. No commercial re-use. See rights and permissions. Published by BMJ.

For numbered affiliations see end of article.

Correspondence to Dr Jessica Leight; j.leight@cgiar.org

\section{ABSTRACT}

Background Intimate partner violence (IPV) is associated with adverse health and psychosocial outcomes. We analysed the spillover effects of Unite for a Better Life (UBL), an intervention evaluated in a cluster randomised controlled trial using a double-randomised design; previous evidence suggests UBL reduced IPV in rural Ethiopia among direct beneficiaries.

Methods Villages $(n=64)$ were randomly allocated to control, or to receive UBL delivered to men, women or couples. Each cluster comprised 106 surveyed households, including 21 randomly selected indirect beneficiary households who were not included in the intervention. Primary and secondary IPV outcomes included women's experience and men's perpetration of past-year physical or sexual IPV 24 months postintervention. An intention-to-treat analysis was conducted comparing indirect beneficiaries to sampled households in control communities. The analysis includes 2516 households surveyed at baseline in 2014-2015 (1680 households in the control arm, 258 indirect beneficiary households in the couples' arm, 287 indirect beneficiary households in the women's arm and 291 indirect beneficiary households in the men's arm). Followup data were available from $88 \%$ of baseline respondents and $86 \%$ of baseline spouses surveyed in 2017-2018, a total of 4379 individuals.

Results Among indirect beneficiaries, there was no statistically significant intervention effect on women's past-year experience of physical or sexual IPV, while men's UBL significantly reduced reported perpetration of pastyear sexual IPV (Adjusted Odds Ratio: 0.55; $95 \% \mathrm{Cl} 0.38$ to $0.80, p=0.002$ ). The intervention effects among indirect beneficiaries were statistically similar to those reported for the direct beneficiaries. In general, the hypothesis of equal effects cannot be rejected.

Conclusion A gender-transformative intervention delivered to men was effective in reducing reported IPV even among indirect beneficiaries, suggesting that the programme had positive spillover effects in diffusing information and changing behaviours within the broader community.

Trial registration numbers NCT02311699 and American Economic Association Registry (AEARCTR-0000211).

\section{Key questions}

What is already known?

- Intimate partner violence (IPV) has serious health consequences for women experiencing violence as well as for their families and communities.

- A growing body of evidence suggests that interventions targeting community-based norms transformation can be effective in preventing IPV, but there is relatively limited evidence about the spillovers of these interventions to individuals who are not directly targeted.

\section{What are the new findings?}

- Unite for a Better Life (UBL), a gender-transformative intervention evaluated in a large-scale doublerandomised controlled trial in southern Ethiopia, effectively reduces reported perpetration of IPV among indirect beneficiaries (members of the broader community in villages targeted by the intervention) when delivered to men.

- The programme also shifts gender norms and HIV risk behaviours among indirect beneficiaries when delivered to men, women and couples.

- In general, the effects for indirect beneficiaries are comparable to the effects for direct beneficiaries, suggesting that intervention messages have effectively diffused through the broader community.

What do the new findings imply?

- Interventions targeting IPV such as UBL can have substantial effects in transforming gender norms and reducing IPV risk in the communities in which these interventions are delivered.

\section{INTRODUCTION}

Globally, intimate partner violence (IPV) poses a major public health challenge with implications for the health and psychosocial well-being of women and their families. ${ }^{1-5}$ IPV prevalence is particularly high in rural Ethiopia, the site of this study, where over $70 \%$ of women have experienced physical and/or 
sexual violence by an intimate partner over the course of their life. ${ }^{3}$

A growing body of literature has evaluated interventions designed to prevent and reduce IPV and shift gender norms by targeting women, ${ }^{6-9}$ men, ${ }^{710}{ }^{11}$ couples $^{12-14}$ or communities. ${ }^{15-18}$ In general, these interventions entail intensive interactions over a defined period with a particular set of participants. These individuals may be those beneficiaries who are explicitly sampled for and invited to participate in the programme, or, in the case of community-level interventions, those beneficiaries who are effectively reached by the mobilisation process.

While these interventions have shown positive effects for direct beneficiaries, there is limited evidence on their spillover effects, defined as impacts beyond those directly targeted. If positive intervention effects diffuse to nonparticipants within communities, this may increase the overall effectiveness and cost-effectiveness of the intervention and contribute to a broader shift in community dynamics. To date, the only two individual-level IPV intervention trials that have analysed spillover effects for indirect beneficiaries assessed the IMAGES and Stepping Stones interventions, and found little evidence of any spillover effects. ${ }^{6}{ }^{19}$ The published community-level IPV intervention trials reported community-level effects without separately analysing effects for beneficiaries directly reached by the programme (eg, programme activists or participants), vis-à-vis community members who are exposed indirectly to programme messages. ${ }^{15-18}$ By contrast, a much larger literature has demonstrated spillover effects of other public health interventions including vaccines, infectious disease interventions, and water and sanitation interventions. ${ }^{2021}$

Unite for a Better Life (UBL) is a gender-transformative intervention designed to reduce physical and sexual IPV and HIV risk behaviours and promote healthier, more equitable relationships. This intervention was delivered to groups of men, women and couples in rural Ethiopia in the context of the traditional coffee ceremony, and evaluated in a cluster-randomised trial. The trial demonstrated the effectiveness of men's UBL in reducing male reported perpetration of past-year sexual IPV, women's reported experience of past-year physical and/or sexual IPV and male reported perpetration of past-year physical and/or sexual IPV. ${ }^{22}$ UBL was also associated with positive effects on a range of other outcomes, including HIV risk behaviours, intrahousehold decision-making, and male involvement in household tasks. ${ }^{22} 23$

The trial included a double-randomised design to allow robust assessment of spillover effects of the intervention. Within communities randomly assigned to the three UBL arms, a second household-level randomisation was conducted to randomly sample a subset of eligible households for inclusion in the intervention. Households that were not invited to participate in the intervention (deemed indirect beneficiaries) were surveyed at baseline and endline in order to measure spillover effects. In this analysis, we assess the programme's effect on women's past-year reported experience of physical or sexual IPV, men's past-year reported perpetration of physical or sexual IPV, HIV risk behaviours, and household gender and power dynamics and task-sharing among the sample of indirect beneficiaries.

\section{METHODS}

\section{Study design}

This paper reports an analysis of data from a subsample of participants in the UBL trial, a four-arm clusterrandomised controlled trial conducted in 64 villages (kebeles) in four districts (Mareko, Meskan, Silte and Sodo) in the Gurague zone of the Southern Nations, Nationalities and People's Region in Ethiopia. Full details of the trial design, data collection, methodology, intervention and main results are provided elsewhere. ${ }^{2223}$ The trial was conducted between 2014 and 2018 by the Abdul Latif Jameel Poverty Action Lab at the Massachusetts Institute of Technology, the Addis Ababa University School of Public Health (AAU), the Ethiopian Public Health Association (EPHA) and EngenderHealth.

\section{Participants}

Within each kebele sampled for inclusion in the trial, one subvillage (gotte) was selected via simple random sampling; subvillages without health extension workers (HEWs) were excluded from the sampling frame. If a subvillage did not have sufficient population to provide an adequate sample, the most proximate subvillage was added to create one sampling unit. The household sampling frame was then constituted using the roster of households maintained by community HEWS, and included all households in which a married or cohabiting couple characterised by a female spouse between the ages of 18 and 49 years was resident. Using this sampling frame, 106 households were randomly selected for inclusion in the baseline survey, and replaced if ineligible. In polygamous households, one woman was selected via simple random sampling. All individuals provided informed oral consent.

\section{Randomisation and masking}

UBL is a group-based intervention; accordingly, a villagelevel cluster-randomised design was employed. ${ }^{20}$ Villages were randomly assigned to one of four study arms (UBL for women, UBL for men, UBL for couples and control) in Stata V.12.0 using a reproducible seed, using districtlevel stratification and an equal allocation ratio. To permit robust assessment of spillover effects, a doublerandomised design was used. ${ }^{24}$ In the second-level randomisation, $80 \%$ of the enrolled trial households in the three UBL arms ( $\mathrm{n}=48$ villages) were randomly selected to participate in UBL ('direct beneficiaries'), while the remaining 20\% were included in baseline and endline data collection ('indirect beneficiaries') for assessment of intervention spillover effects. Note that in indirect beneficiary households no household member was sampled for participation in UBL, while in direct beneficiary 
households, one (men's UBL, women's UBL) or both spouses (couples' UBL) were sampled for intervention participation. This analysis focuses on this random subsample of indirect beneficiaries, and reports only limited results among the larger sample of direct beneficiaries.

Blinding of sampled individuals in the direct beneficiary households in treatment communities was not possible, as they were informed of their treatment assignment when invited to participate in the intervention. Individuals in the indirect beneficiary sample may have heard about or observed intervention activities within their communities. Control communities may have been blind to their inclusion in the trial. Data collection staff were blind to treatment assignment at baseline, but at endline may have observed materials linked to the intervention assignments.

\section{Procedures}

Baseline surveys were conducted among all sampled individuals from November 2014 to March 2015. At baseline, households within villages were further assigned to the men's survey subarm (in which the male spouse was surveyed at baseline) or the women's survey subarm (in which the female spouse was surveyed at baseline), independent of treatment assignment. Accordingly, only one member of each household was surveyed at baseline. Following the baseline survey and treatment randomisation, the UBL intervention was implemented between April 2015 and October 2015. Follow-up surveys were conducted with baseline respondents and their spouses between March 2017 and October 2017, approximately 24 months postintervention. To minimise attrition, additional endline data collection was conducted between January and March 2018.

\section{Intervention}

UBL is a gender-transformative intervention delivered within the context of the Ethiopian coffee ceremony, a culturally established forum for community discussion and conflict resolution. The core objectives are to assist participants in identifying and transforming power imbalances within their relationships, and building skills for healthy, non-violent, equitable relationships. The intervention was implemented by a targeted programme team engaged by EPHA, in an environment where this form of gender-transformative programming was relatively novel.

The intervention was delivered by a team of 48 facilitators, selected by the programme team following a competitive interview process. There were female facilitators for women's groups, men's facilitators for men's groups and both male and female facilitators for couples' groups. Facilitators were selected based on previous experience working in the fields of HIV/AIDS or gender, some previous facilitation skills, and ability to read and write in Amharic. Once selected, they were first required to complete the programme as participants during the piloting of the intervention in order to learn the curriculum, observe implementation by experienced facilitators, and to critically reflect on their own assumptions around gender, sexuality and IPV. Following this process, the facilitators were engaged in a 10-day course which included training in participatory learning and facilitation, and safeguarding procedures.

The UBL curricula include 14 participatory and skillsbuilding sessions, and each session includes a coffee ceremony, discussion and interactive activities focused on gender norms, sexuality, communication and conflict resolution, HIV/AIDS, and IPV. Both men and women are engaged in conducting the coffee ceremony in all three arms, despite the fact that this is a traditionally female role. Facilitators (both men and women) prepare the coffee in the first two sessions to model engagement in the ceremony, and all participants played this role on a rotating basis in subsequent weeks. This intentional utilisation of the coffee ceremony provided an opportunity for facilitators to model non-traditional gender roles, promote equitable behaviours and at the same time increase the cultural relevance of the programme. It also served as an entry point to discuss various topics related to gender norms, power and sexuality.

The intervention was first implemented in Meskan and Mareko districts (April to June 2015), and second in Silte and Sodo districts (August to October 2015). Women and men in the control group received a short educational session on IPV and HIV/AIDS prevention.

\section{Outcomes}

This paper reports an analysis of effects for the indirect beneficiary sample; for consistency, the outcomes of interest are parallel to those analysed for the direct beneficiary sample. This includes primary outcomes prespecified in the clinical trials registry, secondary outcomes prespecified in the registry and additional outcomes included in a preanalysis plan registered prior to analysis (online supplemental file). Primary outcomes include past-year experience of physical IPV and past-year experience of sexual IPV, both reported by women. Secondary IPV outcomes include past-year male reported perpetration of physical IPV and past-year reported male perpetration of sexual IPV. Additional IPV variables include past-year reported experience and perpetration of emotional IPV, and composite measures capturing pastyear reported experience and perpetration of physical and/or sexual IPV.

Non-IPV prespecified secondary outcomes include comprehensive HIV/AIDS knowledge, and condom use at high-risk sexual intercourse. The latter was deemed infeasible given the low levels of reported high-risk sexual intercourse among married couples within this population; accordingly, we analysed condom use at last intercourse. Additional non-IPV outcomes include other HIV-related attitudes and behaviours as well as household task-sharing, decision-making and gender norms. Table 1 summarises the key outcome measures assessed. 
Table 1 Key outcome measures

\section{Variable}

Experienced physical violence from Women partner in past 12 months*

\section{Respondent}

\begin{tabular}{|c|c|c|c|}
\hline $\begin{array}{l}\text { Experienced sexual violence from } \\
\text { partner in the past } 12 \text { months }\end{array}$ & Women & $\begin{array}{l}\text { Women were asked three items } \\
\text { regarding whether their partner } \\
\text { had ever done the following } \\
\text { in the past } 12 \text { months: (1) } \\
\text { physically force you to have } \\
\text { sexual intercourse with him even } \\
\text { when you did not want to; (2) } \\
\text { force you to perform sexual acts } \\
\text { that you did not want to; (3) did } \\
\text { you ever have sexual intercourse } \\
\text { because you were intimidated } \\
\text { by him or afraid he would hurt } \\
\text { you? Responses ranged from } \\
0=\text { no, } 1=y e s .\end{array}$ & $\begin{array}{l}\text { Binary; coded as } 1 \text { if } \\
\text { responded yes to any of the } \\
\text { three items, and } 0 \text { if no to all. }\end{array}$ \\
\hline $\begin{array}{l}\text { Experienced physical and/or sexual } \\
\text { violence from partner in the past } 12 \\
\text { months }\end{array}$ & Women & $\begin{array}{l}\text { Includes the six physical } \\
\text { violence items and three sexual } \\
\text { violence items above. }\end{array}$ & $\begin{array}{l}\text { Binary; coded as } 1 \text { if } \\
\text { responded yes to any of the } \\
\text { nine items, and } 0 \text { if no to all. }\end{array}$ \\
\hline $\begin{array}{l}\text { Experienced emotional violence from } \\
\text { partner in the past } 12 \text { months }\end{array}$ & Women & $\begin{array}{l}\text { Women were asked five items } \\
\text { adapted from the WHO multi- } \\
\text { country study, }{ }^{6} \text { regarding } \\
\text { whether their partner had } \\
\text { ever done the following in the } \\
\text { past } 12 \text { months: (1) insulted } \\
\text { you or made you feel bad } \\
\text { about yourself: (2) belittled or } \\
\text { humiliated you in front of other } \\
\text { people; (3) done things to scare } \\
\text { or intimidate you on purpose } \\
\text { (eg, by the way he looked at } \\
\text { you, by yelling, by smashing } \\
\text { things)?; (4) threatened to } \\
\text { hurt you or someone you care } \\
\text { about? Responses ranged from } \\
0=\text { no, } 1=y e s .\end{array}$ & $\begin{array}{l}\text { Binary; coded as } 1 \text { if } \\
\text { responded yes to any of the } \\
\text { four items, and } 0 \text { if no to all. }\end{array}$ \\
\hline
\end{tabular}

Indicator

Women were asked six items adapted from the WHO multicountry study, ${ }^{6}$ regarding whether their partner had ever done the following in the past 12 months: (1) slapped you or threw something at you that could hurt you; (2) pushed or shoved you; (3) hit you with a fist or with something that could hurt you; (4) kicked you, dragged you or beat you up; (5) choked or burned you on purpose; (6) threatened to use or actually used a gun, knife or other weapon against you. Responses ranged from $0=$ no, $1=$ yes.

\section{Coding}

Binary; coded as 1 if responded yes to any of the six items, and 0 if no to all. physically force you to have sexual intercourse with him even when you did not want to; (2) force you to perform sexual acts that you did not want to; (3) did ou ever have sexual intercourse you? Responses ranged from $0=$ no, $1=y e s$.

violence items and three sexual

Women were asked five items adapted from the WHO multicountry study, ${ }^{6}$ regarding whether their partner had ever done the following in the about yourself: (2) belittled or humiliated you in front of other people; (3) done things to scare or intimidate you on purpose (eg, by the way he looked at you, by yelling, by smashing )?, (4) threatened to about? Responses ranged from . 


\begin{tabular}{|c|c|c|c|}
\hline Variable & Respondent & Indicator & Coding \\
\hline $\begin{array}{l}\text { Perpetrated physical violence against } \\
\text { partner in past } 12 \text { months } \dagger\end{array}$ & Men & $\begin{array}{l}\text { Men were asked six items } \\
\text { adapted from the WHO multi- } \\
\text { country study, }{ }^{6} \text { regarding } \\
\text { whether they had ever done the } \\
\text { following against their partner in } \\
\text { the past } 12 \text { months: (1) slapped } \\
\text { her or threw something at her } \\
\text { that could hurt her; (2) pushed } \\
\text { or shoved her; (3) hit her with a } \\
\text { fist or with something that could } \\
\text { hurt her; (4) kicked her, dragged } \\
\text { her or beat her up; (5) choked } \\
\text { or burned her on purpose; (6) } \\
\text { threatened to use or actually } \\
\text { used a gun, knife or other } \\
\text { weapon against her. Responses } \\
\text { ranged from } 0=\text { no, } 1=y e s .\end{array}$ & $\begin{array}{l}\text { Binary; coded as } 1 \text { if } \\
\text { responded yes to any of the } \\
\text { six items, and } 0 \text { if no to all. }\end{array}$ \\
\hline $\begin{array}{l}\text { Perpetrated sexual violence against } \\
\text { partner in the past } 12 \text { months } \dagger\end{array}$ & Men & $\begin{array}{l}\text { Men were asked three items } \\
\text { regarding whether they had } \\
\text { ever done the following to their } \\
\text { partner in the past } 12 \text { months: } \\
\text { (1) physically force her to have } \\
\text { sexual intercourse with him even } \\
\text { when she did not want to; (2) } \\
\text { force her to perform sexual acts } \\
\text { that she did not want to; (3) did } \\
\text { she ever have sexual intercourse } \\
\text { because she was intimidated by } \\
\text { him or afraid he would hurt her? } \\
\text { Responses ranged from } 0=\text { no, } \\
1=y e s .\end{array}$ & $\begin{array}{l}\text { Binary; coded as } 1 \text { if } \\
\text { responded yes to any of the } \\
\text { three items, and } 0 \text { if no to all. }\end{array}$ \\
\hline $\begin{array}{l}\text { Perpetrated physical and/or sexual } \\
\text { violence against partner in the past } 12 \\
\text { months }\end{array}$ & Men & $\begin{array}{l}\text { Includes the six physical } \\
\text { violence items and three sexual } \\
\text { violence items above. }\end{array}$ & $\begin{array}{l}\text { Binary; coded as } 1 \text { if } \\
\text { responded yes to any of the } \\
\text { nine items, and } 0 \text { if no to all. }\end{array}$ \\
\hline $\begin{array}{l}\text { Perpetratedemotional violenceagainst } \\
\text { partner in thepast } 12 \text { months }\end{array}$ & Men & $\begin{array}{l}\text { Men were asked five items } \\
\text { adapted from the WHO } \\
\text { multicountry study, }{ }^{6} \text { regarding } \\
\text { whether they had ever done } \\
\text { thefollowing against their } \\
\text { partner in the past } 12 \text { months: } \\
\text { 1)Insulted her or made her feel } \\
\text { bad about yourself: } 2 \text { ) Belittledor } \\
\text { humiliated her in front of other } \\
\text { people; } 3 \text { ) Done things toscare } \\
\text { or intimidate her on purpose } \\
\text { (e.g. by the way youlooked at } \\
\text { her, by yelling, by smashing } \\
\text { things)?; 4) Threatenedto hurt } \\
\text { her or someone she cares } \\
\text { about? Responses rangedfrom0 } \\
\text { = no, } 1 \text { = yes. }\end{array}$ & $\begin{array}{l}\text { Binary; coded as } 1 \text { if } \\
\text { responded yes to any of the } \\
\text { four items, and } 0 \text { if no to all. }\end{array}$ \\
\hline
\end{tabular}




\section{Table 1 Continued}

\begin{tabular}{ll}
\hline Variable & Respondent \\
\hline Comprehensive knowledge on HIV $\dagger$ & Women; men
\end{tabular}

Comprehensive knowledge on HIV $\dagger \quad$ Women; men

Respondents were asked the

following questions: (1) can

people reduce their chance of getting the AIDS virus by having just one uninfected sex partner who has no other sex partners?;

(2) can people get the AIDS virus from mosquito bites?; (3) can people reduce their chance of getting the AIDS virus by using a condom every time they have sex?; (4) can people get the AIDS virus because of witchcraft, God's curse, or other supernatural means?;

(5) do you think that a healthylooking person can have HIV? Responses ranged from $1=y e s$, 2=no, 3=do not know.

\begin{tabular}{|c|c|c|}
\hline Used condom at last intercourse $†$ & Women; men & $\begin{array}{l}\text { Respondents were asked: did } \\
\text { you use a condom last time you } \\
\text { had sex? Responses ranged for } \\
0=\text { no, } 1 \text { =yes. }\end{array}$ \\
\hline Confidence in ability to use a condom & Women; men & $\begin{array}{l}\text { Respondents were asked } \\
\text { the following question: how } \\
\text { confident are you that you know } \\
\text { how to correctly use a condom? } \\
\text { Responses ranged from } 1=\text { not } \\
\text { at all confident, } 2=\text { somewhat } \\
\text { confident, } 3=\text { confident, } 4=\text { very } \\
\text { confident. }\end{array}$ \\
\hline
\end{tabular}

\begin{tabular}{|c|c|c|c|}
\hline Ever been tested for HIV & Women; men & $\begin{array}{l}\text { Respondents were asked the } \\
\text { following question: I do not want } \\
\text { to know the results, but have } \\
\text { you ever had a blood test for } \\
\text { HIV?. Responses ranged from } \\
0=\text { no, } 1=\text { yes. }\end{array}$ & $\begin{array}{l}\text { Binary; coded as } 1 \text { if have } \\
\text { had an HIV test, and } 0 \text { if } \\
\text { never had an HIV test. }\end{array}$ \\
\hline $\begin{array}{l}\text { Discussed HIV risk with partner in the } \\
\text { past } 12 \text { months }\end{array}$ & Women; men & $\begin{array}{l}\text { Respondents were asked if } \\
\text { they have discussed HIV risk } \\
\text { behaviour with their partner in } \\
\text { the last } 12 \text { months. Responses } \\
\text { ranged from } 0=\text { no, } 1=\text { yes. }\end{array}$ & $\begin{array}{l}\text { Binary; coded as } 1 \text { if have } \\
\text { discussed HIV risk, and } 0 \text { if } \\
\text { have not discussed HIV risk. }\end{array}$ \\
\hline $\begin{array}{l}\text { Discussed sex with partner in the past } \\
12 \text { months }\end{array}$ & Women; men & $\begin{array}{l}\text { Respondents were asked if they } \\
\text { have discussed sex with their } \\
\text { partner in the last } 12 \text { months. } \\
\text { Responses ranged from } 0=\text { no, } \\
1=\text { yes. }\end{array}$ & $\begin{array}{l}\text { Binary; coded as } 1 \text { if have } \\
\text { discussed sex, and } 0 \text { if have } \\
\text { not discussed sex. }\end{array}$ \\
\hline
\end{tabular}

Knowledge, attitudes and behaviours related to IPV

$\begin{array}{ll}\text { Knowledge of laws related to IPV } \quad \text { Women; men } & \begin{array}{l}\text { Respondents were asked two } \\ \text { questions: (1) according to the }\end{array} \text { responded correctly to } \\ \text { both questions (yes to both } \\ \text { law, is a husband who forces } \\ \text { his wife to have sex against her questions). } \\ \text { will committing a criminal act (ie, } \\ \text { the husband can be fined or put } \\ \text { in jail)?; (2) are there any laws } \\ \text { in your country about violence } \\ \text { against women? Responses } \\ \text { ranged from } 0=\text { no, } 1=\text { yes, } 2=\text { do } \\ \text { not know. }\end{array}$

Binary; coded as 1 if used condom at last sex, and 0 if did not use condom at last sex.

Binary; coded as 1 if responded confident or very confident, 0 if not at all confident or somewhat confident. 
Table 1 Continued

\begin{tabular}{ll}
\hline Variable & Respondent \\
\hline Support for gender equitable norms & Women; men
\end{tabular}

Indicator

Coding

Support for gender equitable norms Women; men

Respondents were asked if they A score was generated by agreed with 13 statements from the Gender Equitable Men's Scale: (1) a man should have the final word on decisions in his home; (2) a woman should obey her husband in all things; (3) it is alright for a man to beat his wife if she is unfaithful; (4) a man can hit his wife if she will not have sex with him; (5) a woman should not initiate sex; (6) a man should be outraged if his wife asks him to use a condom; (7) it is a woman's responsibility to avoid getting pregnant; (8) a woman who has sex before she marries does not deserve respect; (9) women should tolerate violence in order to keep her family together; (10) there are times a woman deserves to be beaten; (11) a man using violence against his wife is a private matter that should not be discussed outside of the couple; (12) it disgusts me when I see a man acting like a woman. Responses ranged from 1 =agree, $2=$ partially agree, $3=$ do not agree.

$\begin{array}{lll}\text { Do not believe that IPV is justified } & \text { Women; men } & \begin{array}{l}\text { Respondents were asked } \\ \text { whether they believe a man has responded no to all } \\ \text { statements and coded as } 0\end{array} \\ & \text { a good reason to beat his wife the following situations: (1) if responded yes to any of } \\ \text { she answers back to him; (2) the statements. } & \text { she neglects taking care of the } \\ \text { children; (3) she burns the food; } & \text { (4) she goes out without telling } \\ \text { him; (5) she refuses to have sex } & \text { with him. Responses ranged } \\ \text { from 1=yes to 2=no. }\end{array}$

Intra-household decision-making and gendered division of childcare and household tasks

\begin{tabular}{|c|c|c|c|}
\hline $\begin{array}{l}\text { Male involvement in household and } \\
\text { child-care tasks }\end{array}$ & Women; men & $\begin{array}{l}\text { Respondents were asked how } \\
\text { they divided four household } \\
\text { tasks that are typically } \\
\text { performed by women: (1) } \\
\text { washing clothes; (2) cleaning the } \\
\text { house; (3) preparing the food; } \\
\text { (4) daily care of the children. } \\
\text { Responses ranged from } \\
1=\text { woman always does the task, } \\
\text { to } 3=\text { shared equally or done } \\
\text { together, to } 5=\text { man always does } \\
\text { the task. }\end{array}$ & $\begin{array}{l}\text { Binary; coded as } 1 \text { if man } \\
\text { contributed to two or more } \\
\text { tasks and } 0 \text { if contributed to } \\
\text { less than two tasks. }\end{array}$ \\
\hline $\begin{array}{l}\text { Men's dominance in decision-making } \\
\text { about food and clothing }\end{array}$ & Women; men & $\begin{array}{l}\text { Respondents were asked who } \\
\text { in their household has the final } \\
\text { say in how you spend money on } \\
\text { food and clothing. Responses } \\
\text { ranged from } 1=\text { woman, } 2=\text { man, } \\
3=\text { both jointly, } 4=\text { someone else. }\end{array}$ & $\begin{array}{l}\text { Binary; coded as } 1 \text { if man } \\
\text { has final say, and as } 0 \text { if } \\
\text { decision made by woman or } \\
\text { made jointly. }\end{array}$ \\
\hline
\end{tabular}
summing the responses to all 12 questions. A binary variable generated, and coded as 1 if respondent scored 24 or higher. 
Table 1 Continued

\begin{tabular}{|c|c|c|c|}
\hline Variable & Respondent & Indicator & Coding \\
\hline $\begin{array}{l}\text { Men's dominance in decision-making } \\
\text { about purchase of large items }\end{array}$ & Women; men & $\begin{array}{l}\text { Respondents were asked who } \\
\text { in their household has the final } \\
\text { say in how you spend money } \\
\text { on large investments such as a } \\
\text { car, or a house or a household } \\
\text { appliance. Responses ranged } \\
\text { from } 1=\text { woman, } 2=\text { man, } 3=\text { both } \\
\text { jointly, } 4=\text { someone else. }\end{array}$ & $\begin{array}{l}\text { Binary; coded as } 1 \text { if man } \\
\text { has final say, and as } 0 \text { if } \\
\text { decision made by woman or } \\
\text { made jointly. }\end{array}$ \\
\hline $\begin{array}{l}\text { Men's dominance in decision-making } \\
\text { about spending time with family and } \\
\text { friends }\end{array}$ & Women; men & $\begin{array}{l}\text { Respondents were asked who in } \\
\text { their household has the final say } \\
\text { regarding spending time with } \\
\text { family or relatives. Responses } \\
\text { ranged from } 1=\text { =woman, } 2=\text { man, } \\
3=\text { both jointly, } 4=\text { someone else. }\end{array}$ & $\begin{array}{l}\text { Binary; coded as } 1 \text { if man } \\
\text { has final say, and as } 0 \text { if } \\
\text { decision made by woman or } \\
\text { made jointly. }\end{array}$ \\
\hline
\end{tabular}

*Primary outcome measures.

†Secondary outcome measures.

IPV, intimate partner violence.

Sample size was determined in order to maximise power to detect experimental effects for the primary outcomes of interest for the sample of direct beneficiaries. ${ }^{21}$ No power calculations were conducted for the analysis of effects for indirect beneficiaries. No interim analysis was conducted.

\section{Statistical analysis}

Characteristics of women and men indirect beneficiaries at baseline are compared across arms using descriptive statistics. UBL information diffusion from direct to indirect beneficiaries is assessed via indicators of information sharing and receipt. To estimate the impact of the interventions on indirect beneficiaries, an intention-to-treat (ITT) analysis is conducted with the $20 \%$ of households selected as indirect beneficiaries at baseline in each UBL arm, and households in the control group. The analysis employs logistic regression models fit with generalised estimating equations and robust SEs clustered at the level of the village and including strata fixed effects for district. ${ }^{25}$ ORs and $95 \%$ CIs are reported for unadjusted and adjusted models. Adjusted models include the following baseline covariates: respondent's age, respondent's education level, marriage length, polygamy, socioeconomic status, whether they completed the full or short questionnaire at endline and months between intervention end and endline data collection. To analyse attrition, the simple (unadjusted) model is also estimated employing a binary variable for attrition as the dependent variable.

A second analysis is conducted including the full sample of surveyed individuals (both direct and indirect beneficiaries) to assess whether the estimated treatment effects are significantly different for individuals sampled for the intervention vis-à-vis indirect beneficiaries. Logistic regression models are fit with generalised estimating equations and cluster-robust SEs, and additionally include interaction terms between the treatment assignment variable and the indicator variable for indirect beneficiaries. For concision, we present only adjusted models, and estimate this model only for the IPV outcomes. As a supplemental analysis, we also estimate this model restricting to the sample of baseline respondents (ie, excluding their spouses).

We also conduct a supplemental analysis of risk differences for the IPV outcomes among the full sample of surveyed individuals (direct and indirect beneficiaries, and both baseline respondents and their spouses). This analysis employs ordinary least squares estimation (linear probability models) using SEs clustered at the village level.

\section{Role of the funding source}

The funders of the study had no role in study design, data collection, analysis, interpretation or writing of the results. The corresponding author (JL) had full access to all data in the study and final responsibility for the decision to submit for publication.

\section{Patient and public involvement}

Implementation of the randomised controlled trial was guided and supported by a community advisory board constituted by local and national stakeholders and policymakers, including representatives of women's groups who work with women experiencing IPV. The community advisory board met regularly for the duration of the study to provide feedback on the design, the intervention and the local context. Findings were also presented first to the board in order to enable their feedback on dissemination.

\section{RESULTS}

Between November 2014 and March 2015, 6770 households in 64 clusters were enrolled in the study (figure 1). Random assignment of clusters to study arms resulted in 


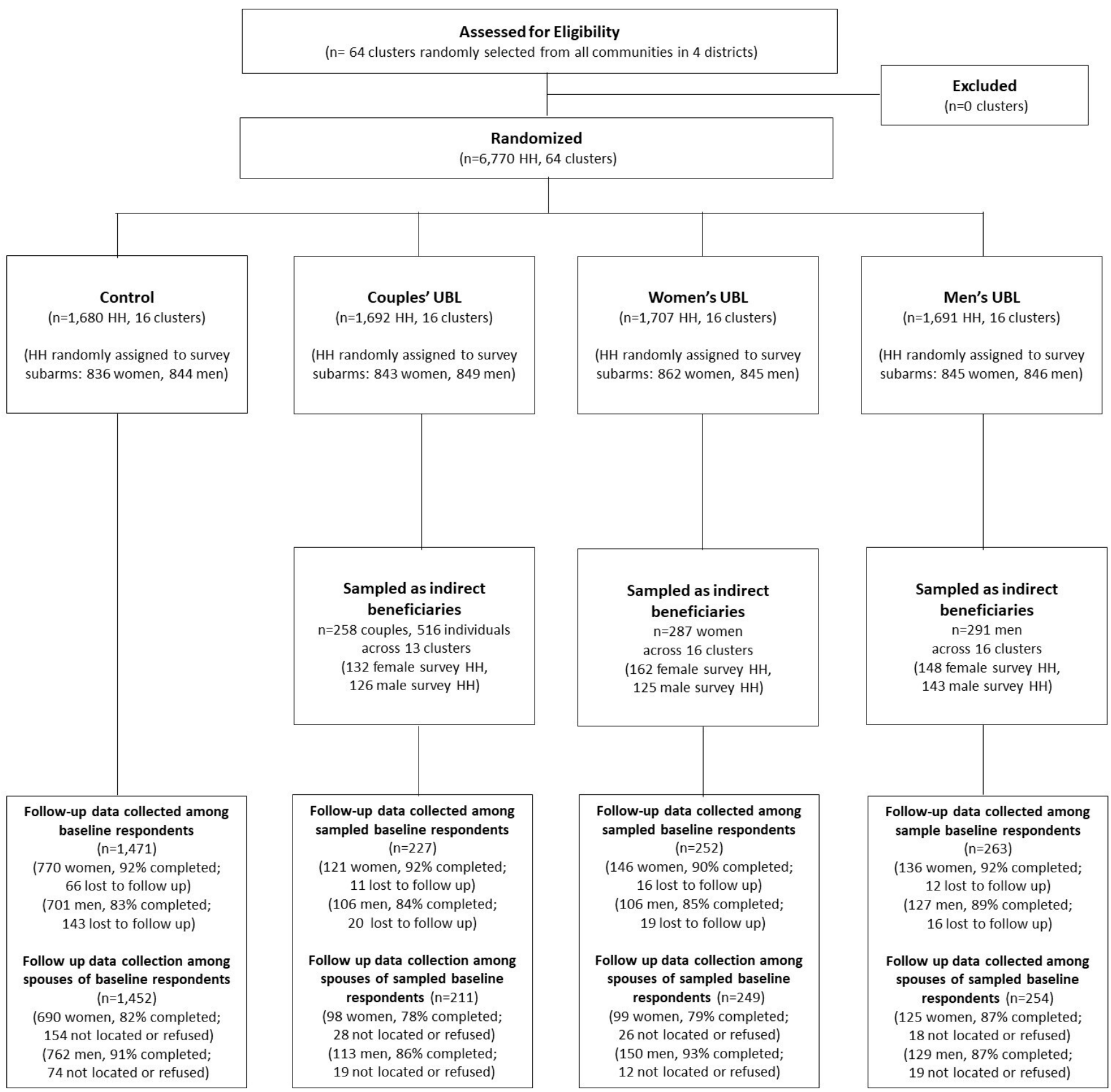

Figure 1 Participant flow diagram.

1680 households in 16 clusters assigned to the control group, 1692 households (1434 direct beneficiaries, 258 indirect) in 16 clusters assigned to the couples' UBL arm, 1707 households (1420 direct beneficiaries, 287 indirect) in 16 clusters were assigned to the women's UBL arm, and 1691 households (1400 direct beneficiaries, 291 indirect) in 16 clusters were assigned to the men's UBL arm.

The second-level randomisation status (ie, randomisation into the direct or indirect beneficiary sample) was not recorded for 222 baseline respondents (including all indirect beneficiaries in three clusters in the couples' arm) due to record-keeping errors. These individuals were coded as direct beneficiaries to generate conservative estimates of the intervention effects for the main analysis. However, this yields a smaller effective sample for the analysis of indirect beneficiaries, and the indirect beneficiary sample then includes only 13 clusters in the couples' arm. Among the sample of interest (the indirect beneficiary subsample of the treatment arms, and the control arm), the endline follow-up rate was $92 \%$ for baseline female respondents, $84 \%$ for baseline male respondents, $82 \%$ for female spouses and $90 \%$ for male spouses. The primary reasons for loss to follow-up included migration, respondent unavailability and respondents' declining to participate.

Limited baseline characteristics are reported in table 2 . Among indirect beneficiaries, women were on average 32 years of age, while men were 37 years. Approximately 
Table 2 Baseline characteristics of women $(\mathrm{N}=1278)$ and men $(\mathrm{N}=1238)$ in the target sample (control arm; indirect beneficiaries in each treatment arm)

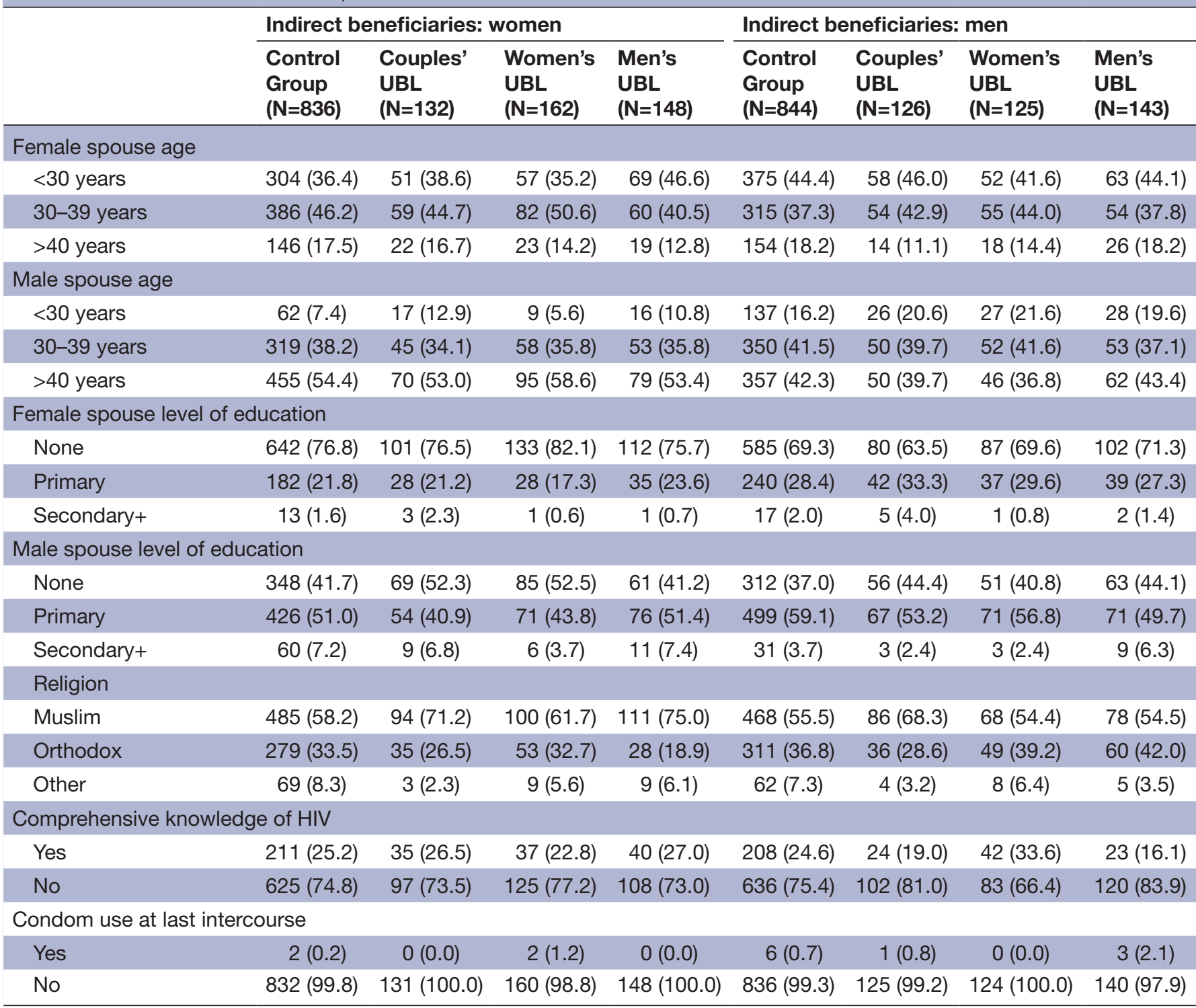

Note that at baseline, only one respondent per household was interviewed according to study subarm assignment. Secondary+ denotes secondary or higher education.

UBL, Unite for a Better Life.

$70 \%$ of women reported having no formal education, versus $40 \%$ of men. The majority of households were Muslim. These characteristics are generally consistent across arms and when comparing indirect beneficiaries (pooled across treatment arms) with direct beneficiaries (pooled across treatment arms), as reported in online supplemental table 1 in online supplemental materials.

Reported diffusion of UBL information from direct beneficiaries to other individuals including spouses (considered direct beneficiaries) as well as indirect beneficiaries (friends, neighbours and other relatives) was generally high (table 3 ). Diffusion was assessed by examining information-sharing by direct beneficiaries, and information receipt by indirect beneficiaries. Among women, $64.9 \%$ of direct beneficiaries in the couples' UBL arm and $81.3 \%$ in the women's UBL arm reported sharing information from UBL sessions with others, while among men, $88.6 \%$ and $93.2 \%$ of direct beneficiaries in the couples' and men's UBL arm, respectively, reported sharing such information. Female direct beneficiaries were most likely to share information with a spouse (in the women's arm) and with a neighbour (in both arms), while reported diffusion to relatives and friends was less common. Male direct beneficiaries were most likely to share information with friends, followed by neighbours (and spouses, in the men's UBL arm) and relatives. Information receipt among indirect beneficiaries was highest for respondents in the arms in which same-sex peers were invited to participate. For example, reported recognition of the programme for women in the women's UBL arm, men in the men's UBL arm, and both men and women in the couples' UBL arm was roughly $70 \%-80 \%$. However, 
Table 3 Information diffusion from direct to indirect beneficiaries among women and men

\begin{tabular}{|c|c|c|c|c|c|c|}
\hline & \multicolumn{3}{|l|}{ Women } & \multicolumn{3}{|l|}{ Men } \\
\hline & $\begin{array}{l}\text { Couples' } \\
\text { UBL } \\
\text { N (\%) }\end{array}$ & $\begin{array}{l}\text { Women's } \\
\text { UBL } \\
\text { N (\%) }\end{array}$ & $\begin{array}{l}\text { Men's } \\
\text { UBL } \\
\text { N (\%) }\end{array}$ & $\begin{array}{l}\text { Couples' } \\
\text { UBL } \\
\text { N (\%) }\end{array}$ & $\begin{array}{l}\text { Women's } \\
\text { UBL } \\
\text { N (\%) }\end{array}$ & $\begin{array}{l}\text { Men's } \\
\text { UBL } \\
\text { N (\%) }\end{array}$ \\
\hline \multicolumn{7}{|c|}{ Information sharing by direct beneficiaries with others } \\
\hline Shared information-anyone & $\begin{array}{l}554 / 853 \\
(64.9)\end{array}$ & $\begin{array}{l}579 / 712 \\
(81.3)\end{array}$ & & $\begin{array}{l}845 / 954 \\
(88.6)\end{array}$ & & $\begin{array}{l}786 / 843 \\
(93.2)\end{array}$ \\
\hline Shared information - spouse & $\begin{array}{l}48 / 554 \\
(8.7)\end{array}$ & $\begin{array}{l}402 / 579 \\
(69.4)\end{array}$ & & $\begin{array}{l}249 / 845 \\
(29.5)\end{array}$ & & $\begin{array}{l}566 / 786 \\
(72.0)\end{array}$ \\
\hline Shared information - relative & $\begin{array}{l}164 / 554 \\
(29.6)\end{array}$ & $\begin{array}{l}128 / 579 \\
(22.1)\end{array}$ & & $\begin{array}{l}475 / 845 \\
(56.2)\end{array}$ & & $\begin{array}{l}338 / 786 \\
(43.0)\end{array}$ \\
\hline Shared information - friend & $\begin{array}{l}279 / 554 \\
(50.4)\end{array}$ & $\begin{array}{l}252 / 579 \\
(43.5)\end{array}$ & & $\begin{array}{l}725 / 845 \\
(85.8)\end{array}$ & & $\begin{array}{l}628 / 786 \\
(79.9)\end{array}$ \\
\hline Shared information-neighbour & $\begin{array}{l}451 / 554 \\
(81.4)\end{array}$ & $\begin{array}{l}421 / 579 \\
(72.7)\end{array}$ & & $\begin{array}{l}653 / 845 \\
(77.3)\end{array}$ & & $\begin{array}{l}560 / 786 \\
(71.2)\end{array}$ \\
\hline \multicolumn{7}{|c|}{ Information receipt by indirect beneficiaries } \\
\hline Remembers UBL & $\begin{array}{l}180 / 219 \\
(82.2)\end{array}$ & $\begin{array}{l}178 / 245 \\
(72.7)\end{array}$ & $\begin{array}{l}128 / 260 \\
(49.2)\end{array}$ & $\begin{array}{l}155 / 219 \\
(70.8)\end{array}$ & $\begin{array}{l}72 / 256 \\
(28.1)\end{array}$ & $\begin{array}{l}173 / 256 \\
(67.6)\end{array}$ \\
\hline
\end{tabular}

Note that information diffusion is reported only by direct beneficiaries who report attending at least one UBL session.

UBL, Unite for a Better Life.

only $49.2 \%$ of women in the men's UBL arm remember the intervention, and only $28.1 \%$ of men in the women's UBL arm.

Table 4 presents IPV outcomes among male and female indirect beneficiaries by treatment arm. Crude and adjusted ORs and 95\% CIs are presented for each outcome comparing the prevalence in each intervention arm versus the control arm as per the ITT analysis. Reported IPV prevalence in the control arm at endline was high; in the past-year, $43 \%$ of women reported experiencing physical and/or sexual IPV, and 39\% of men reported perpetrating physical and/or sexual IPV.

For the primary and secondary IPV outcomes, there was no effect of the intervention on experience of pastyear physical or sexual IPV among women indirect beneficiaries across any of the treatment arms. However, men's UBL generated large and significant reductions in male indirect beneficiaries' reported perpetration of past-year sexual IPV (AOR $0.55,95 \%$ CI 0.38 to 0.81 , $\mathrm{p}=0.002)$. In addition, there is an increase in male indirect beneficiaries' reported perpetration of physical IPV in the couples' arm (AOR 1.49, 95\% CI 1.08 to $2.05, \mathrm{p}=0.016)$. For additional IPV variables, there is no evidence of any significant treatment effect of UBL on women's reported experience of past-year physical and/ or sexual IPV, or past-year emotional IPV, among indirect beneficiaries. However, there is a significant reduction in men's reported perpetration of past-year physical and/ or sexual IPV (AOR 0.71, 95\% CI 0.52 to $0.97, \mathrm{p}=0.030$ ) among indirect beneficiaries, but no shift in reported perpetration of past-year emotional IPV.

HIV-related outcomes and knowledge, attitudes and intrahousehold behaviour for female indirect beneficiaries are reported in table 5. For prespecified secondary outcomes, there is an increase in comprehensive HIV knowledge (AOR 1.81, 95\% CI 1.03 to 3.81, $\mathrm{p}=0.040$ ) and reported condom use at last intercourse (AOR 5.93, 95\% CI 1.42 to $24.75, \mathrm{p}=0.015$ ), both in the women's UBL arm only. For additional outcomes linked to norms and decision-making, there is evidence of statistically significant increases in knowledge of IPV laws (in the women's UBL arm), and support for gender equitable norms (in the couples' UBL arm), and decreased male dominance in decision-making (in the women's and couples' UBL arms). For additional HIV outcomes, there is evidence of statistically significant increases in confidence in ability to use a condom and reported HIV testing (in the women's and couples' UBL arms), and in discussing HIV risk and sex with their partners (in the women's and men's UBL arms).

Parallel results for male indirect beneficiaries are reported in table 6 . There is no evidence of any statistically significant change in comprehensive HIV knowledge and condom use at last intercourse. For additional outcomes linked to norms and decision-making, there is evidence of statistically significant increased knowledge of IPV laws (in the men's UBL arm), and decreased male dominance in decision-making (in the couples' and men's UBL arms). For additional HIV outcomes, there is evidence of statistically significant increases in reported confidence in condom use, HIV testing and communicating with partners about HIV risk and sex (in the couples' and men's UBL arms).

To analyse attrition, online supplemental table 2 reports the results of estimating the simple, unadjusted model employing attrition from the endline survey as the outcome variable. There is no evidence that attrition is significantly associated with treatment assignment among 


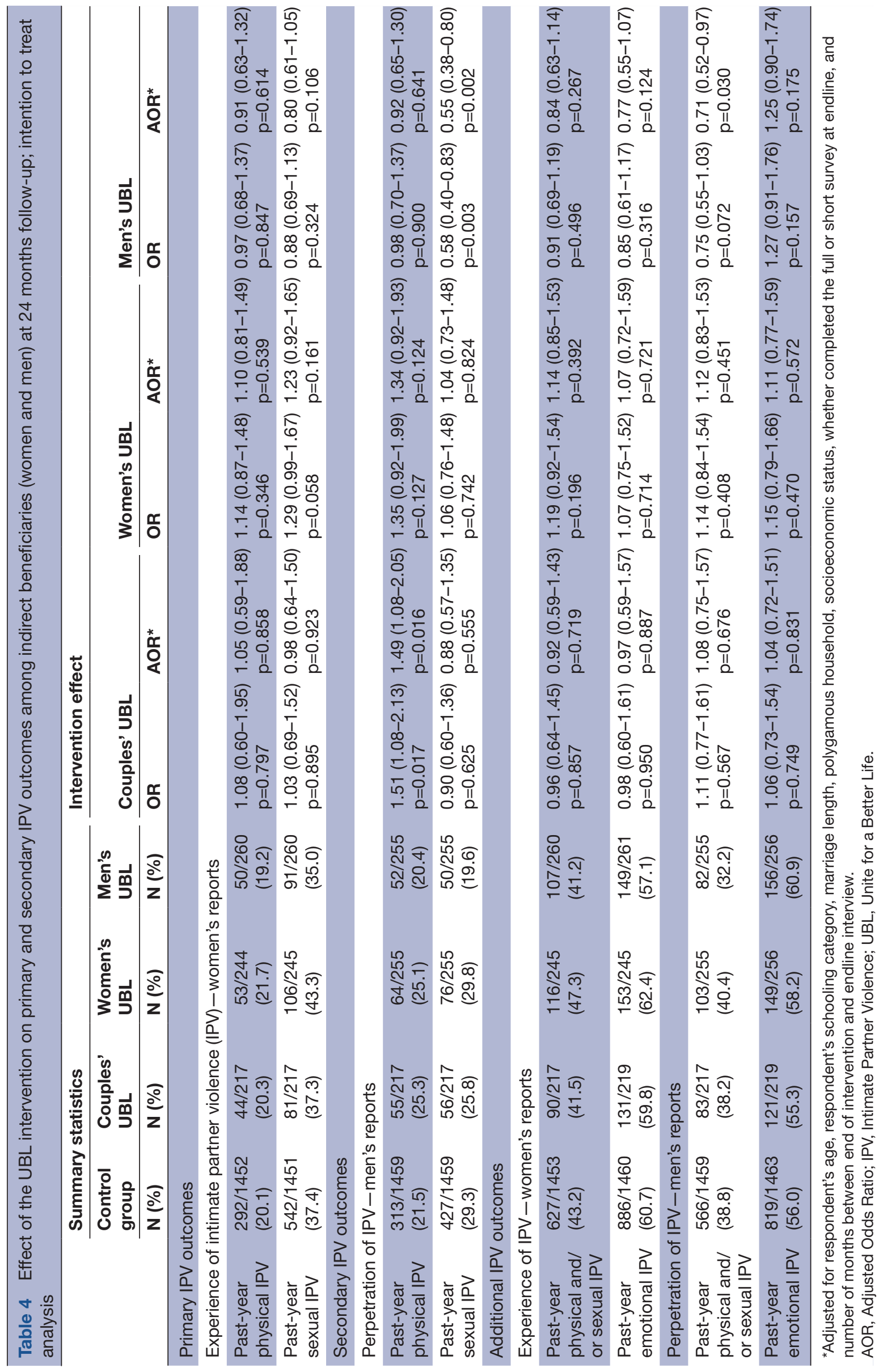




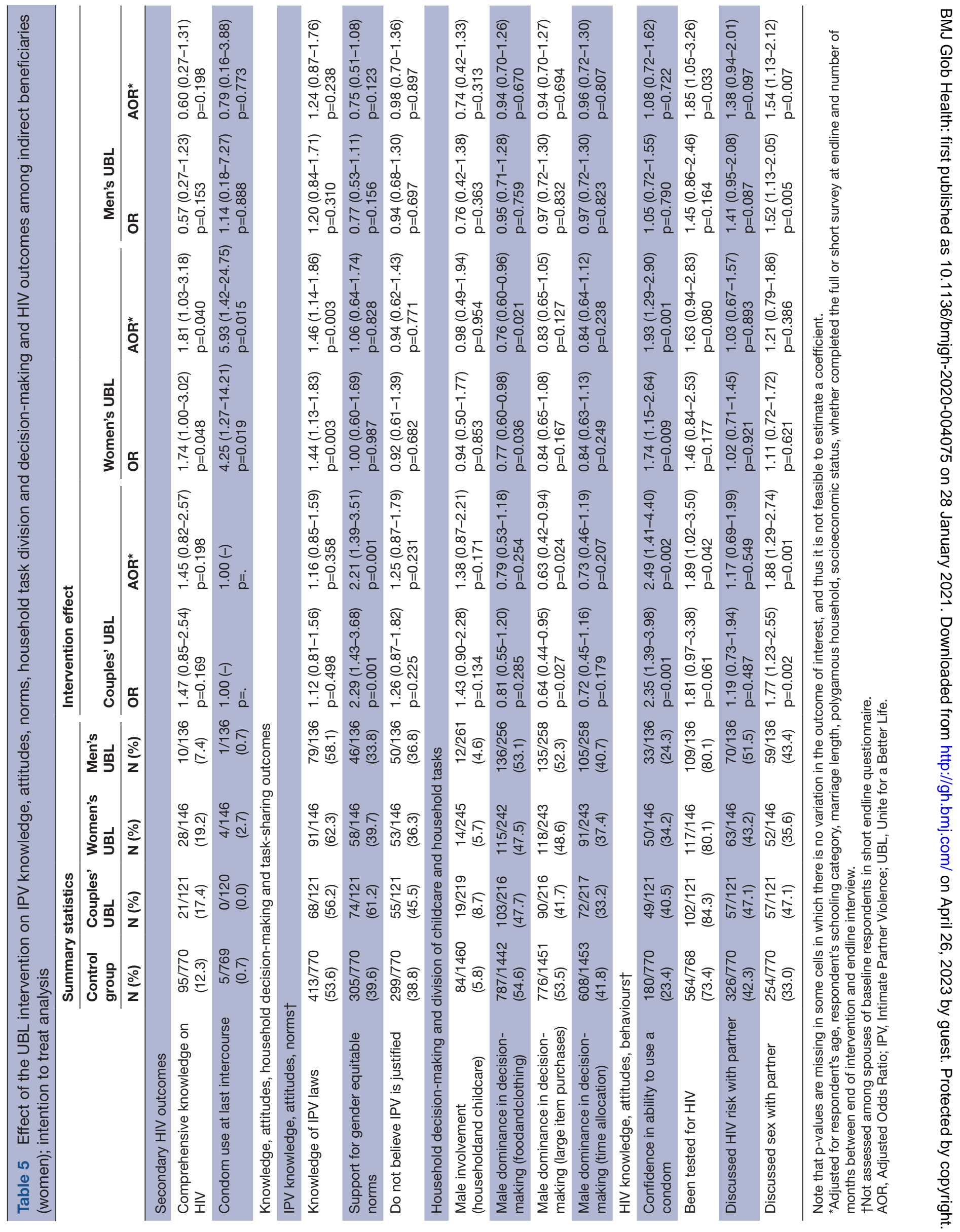




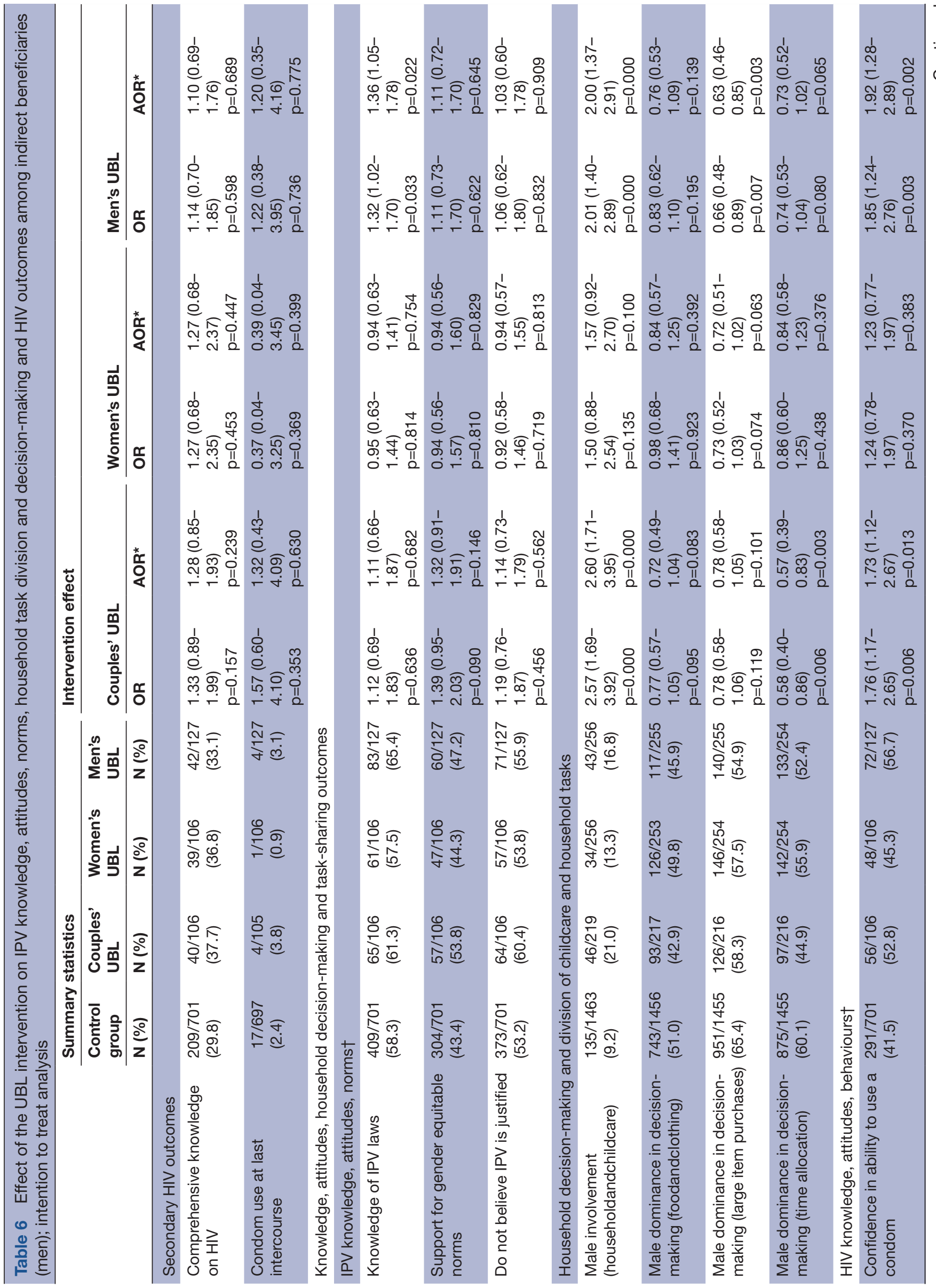




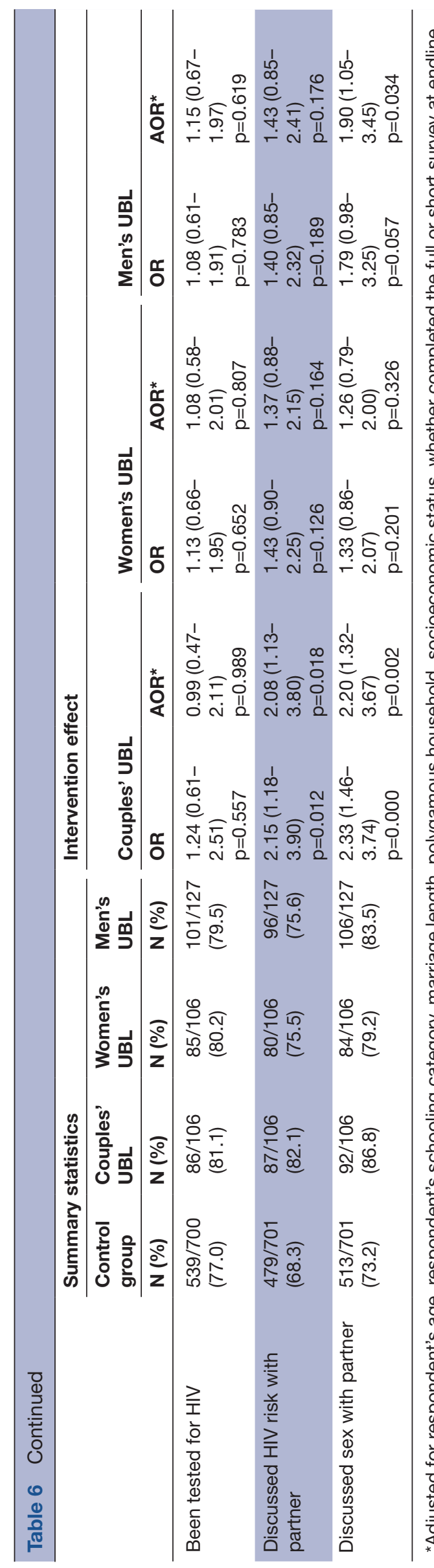

female or male baseline respondents or their spouses, and no evidence of a significant association in the pooled sample.

Table 7 presents the results from the covariate-adjusted model including the full sample (direct and indirect beneficiaries) and interacting treatment assignment with an indicator variable for indirect beneficiaries. The adjusted ORs for the outcome of interest as well as the interaction terms are presented; we focus on the estimated interaction effects. In general, the interaction terms are not statistically significant, suggesting that the hypothesis that intervention effects are consistent across direct and indirect beneficiaries cannot be rejected. For the primary outcome variables, the interaction terms are uniformly insignificant. For secondary outcome variables, there is a statistically significant increase in reported male perpetration of past-year physical IPV only among indirect beneficiaries compared with direct beneficiaries in communities assigned to the couples' UBL arm (interaction term AOR $1.53,95 \%$ CI 1.21 to $1.93, p=0.000$ ). A similar pattern is observed for reported male perpetration of past-year physical and/or sexual IPV (interaction term AOR 1.27, 95\% CI 1.02 to $1.59, \mathrm{p}=0.035$ ). These results are also consistent when restricted to the sample of baseline respondents only, as reported in online supplemental table 3 . Additional results of specifications parallel to table 6 , but evaluating risk differences are reported in online supplemental table 4 .

\section{DISCUSSION}

The UBL intervention had large and significant effects on a number of IPV outcomes as well as norms and behaviour related to gender equity and HIV among indirect beneficiaries who were not directly exposed to intervention programming. The intervention effects among indirect beneficiaries were broadly similar to those reported for the direct beneficiaries on a range of outcomes (in general, the hypothesis of equal effects cannot be rejected), indicating that indirect beneficiaries who did not participate in the programme benefited as much as direct participants. ${ }^{23}$

More specifically, the results are consistent with a decrease in men's reported perpetration of past-year sexual IPV and physical and/or sexual IPV among indirect beneficiaries in communities where the men's UBL intervention was implemented. However, the observed decrease in perpetration of IPV as reported by men is only weakly corroborated by women's reports; there is evidence of a decrease in reported experience of sexual IPV in the men's arm, but it is not statistically significant. In addition, there is evidence of enhanced support for gender equitable norms, increased male task-sharing, and decreased male domination in spousal decisionmaking in communities where the couples' and men's UBL intervention was implemented, as well as some limited evidence of effects in communities where the women's UBL intervention was implemented. There was 


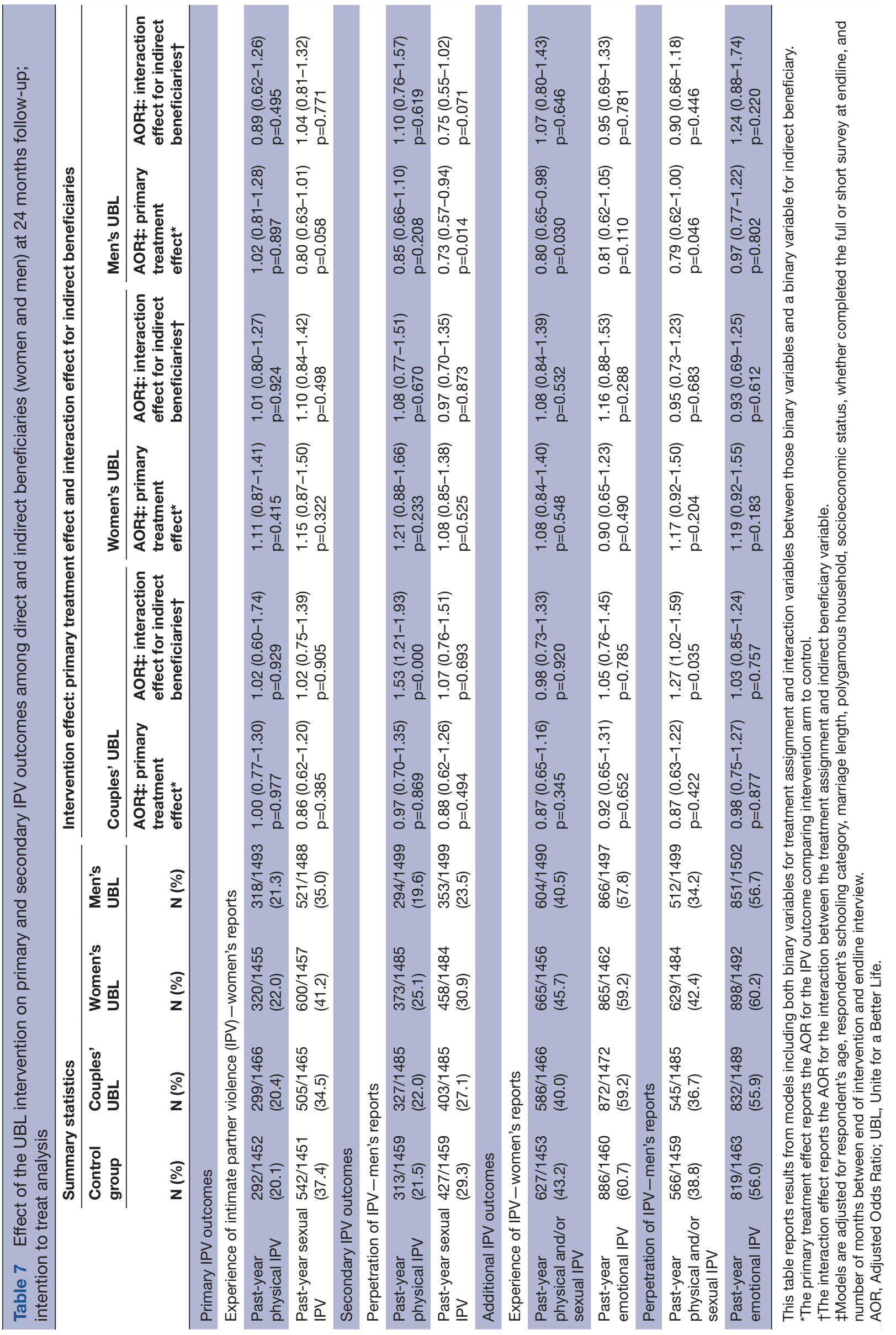


no reported increase in gender equitable norms among men, and very limited evidence of shifts in male dominance in decision-making as reported by women. Shifts in HIV knowledge and behaviours are observed for indirect beneficiaries in all three arms.

This paper is among the first to report robust and meaningful spillover effects of an IPV prevention intervention among indirect beneficiaries, as previous evidence from IMAGES and Stepping Stones found little direct evidence of diffusion from programme participants to other indirect beneficiaries. ${ }^{6} 19$ Other major interventions, such as SASA!, Indashyikirwa and SHARE were targeted at the community level and thus there is no clear distinction between direct and indirect beneficiaries, ${ }^{15-18}$ though in the case of SASA! a follow-up analysis examined patterns of diffusion. ${ }^{26}$ The UBL trial was designed from the outset to robustly assess spillover effects by employing a doublerandomised design in which the sample of indirect beneficiaries is randomly selected from the population eligible for the intervention. ${ }^{27}$ Accordingly, the samples of direct and indirect beneficiaries in the treatment arms are comparable to each other and to respondents in the control arm on both observable and unobservable characteristics, as verified using baseline data. This allows us to conduct an ITT analysis and estimate the causal impact of indirect exposure to the intervention on the outcomes of interest.

The only other data supporting diffusion of social norms interventions can be found in two recent papers. ${ }^{28}$ One paper presents three case studies of diffusion, two of which focus on IPV interventions (Change Starts at Home in Nepal and Voices for Change in Nigeria). In both case studies, respondents who were exposed to higher levels of diffusion of intervention messaging report more significant attitudinal or behavioural change, but the analyses are not able to clearly attribute causality. A second paper analyses qualitative and correlational evidence from SASA! communities and identified an association between interpersonal communication with change agents and behavioural change linked to IPV. ${ }^{26}$ Additional evaluations of IPV interventions targeted at men, women and couples have not collected data from indirect beneficiaries. ${ }^{7-10} 1213$

The broader literature analysing health education and behavioural change interventions provides relatively little evidence on spillover effects for indirect beneficiaries in low-income and middle-income countries, though there is a much larger literature around spillover effects for vaccine and infectious disease interventions. A recent systematic review found 54 papers reporting spillover effects of health interventions in low-income and middleincome countries, but only five were health education interventions. $^{20}$ Two papers have analysed spillover effects of sexual education interventions within schools, presenting heterogeneous evidence; in Colombia, there is no evidence of diffusion of a sexual education intervention across classrooms, ${ }^{29}$ while in Kenya, there is evidence of diffusion from older to younger student cohorts. ${ }^{30}$
The UBL intervention has several characteristics that may have led to meaningful effects for indirect beneficiaries. First, UBL facilitators were recruited and trained within the study districts, and were intended to be credible leaders in shifting norms within these communities. The training process for facilitators also entailed their participation in the UBL intervention itself, to allow them to critically examine and revise their own gender norms. This training process may have rendered facilitators particularly qualified to transmit messages that would be well-received by both direct beneficiaries and the broader community.

Second, the UBL intervention was purposively designed to maximise the potential for information diffusion, or 'organised diffusion', defined as the sharing of knowledge encouraged by practitioners and led by programme participants. ${ }^{28}$ The discussions were nested within an important cultural ceremony-the coffee ceremonythat serves as an anchor for community discussion in Ethiopia. ${ }^{31}$ Moreover, the coffee ceremony is traditionally viewed as the purview of women, while in this intervention, both female and male facilitators led coffee ceremonies, and they engaged both female and male participants in conducting the ceremony on a rotating basis. The inclusion of men in a traditionally female space may have been particularly notable, and increased the salience of the intervention and its messaging for non-participants. In addition, the intervention directly encouraged participants to contribute to information diffusion, and some commitments to action (suggested follow-up actions by participants) required participants to engage in discussions about UBL content with others. The explicit engagement of participants in the process may have enabled relatively rapid intervention diffusion: the UBL intervention itself lasted only 7 weeks, and significant diffusion effects were observed in a follow-up period of 24 months.

Third, this intervention was conducted in rural communities in a context characterised by low levels of education and socioeconomic status; within households sampled at baseline, approximately $75 \%$ of women reported no education, and approximately $50 \%$ of men reported no education. Previous interventions targeting IPV have generally been evaluated in higher-education contexts such as South Africa, ${ }^{6} 7$ Rwanda, ${ }^{12}$ urban Uganda ${ }^{15}$ and urban India. ${ }^{8}$ Only one previously published trial focusing on rural north and northwestern Côte d'Ivoire analysed a sample with similarly low levels of education. ${ }^{13}$ A separate trial analysing a different sample in Côte d'Ivoire also reported much higher levels of education at baseline. ${ }^{10}$ Information transmission within social networks may be particularly salient in rural and low education communities in which access to more formal communications channels is limited. ${ }^{32}$

Fourth, saturation of UBL within communities may have been an important factor. Approximately $10 \%$ of households within treatment communities were sampled as direct participants in the intervention. However, 
villages in this setting are organised into smaller units called subvillages (gottes), and at the gotte level, saturation would be higher, roughly $40 \%$. The systematic review of health intervention spillover findings suggests greater spillover effects with higher treatment coverage, with most studies reporting significant spillovers to have surpassed the threshold of $50 \%$ cluster-level treatment coverage. ${ }^{20}$ We are not able to assess association between variation in levels of coverage and spillover effects in this trial, but it is plausible to hypothesise that UBL spillover effects would not have been as widespread with lower intervention coverage within villages. This is an important consideration when planning for intervention implementation and scale up in order to maximise intervention benefits and cost-effectiveness.

Analysis of the spillover effects for indirect beneficiaries also highlights some intervention risks that were not evident for direct beneficiaries. In particular, there is evidence of increased reported male perpetration of past-year physical IPV and physical and/or sexual IPV among indirect beneficiaries in couples' UBL communities, while there was no evidence of this effect among the sample of direct beneficiaries. ${ }^{22}$ Importantly, this increase is not corroborated by women indirect beneficiaries in the couples' UBL communities, who do not report any statistically significant increase in past-year experience of physical IPV.

One interpretation of this pattern is that transmission of alternate norms around IPV among indirect beneficiaries who do not receive some of the interventions' foundational training on power relations and couples' communication may increase the risk of intrahousehold conflict that leads to violence. The diffusion channels themselves may also be relevant. For example, in the couples' arm, both men and women may be exposed to diffusion of intervention messaging through separate same-sex networks. If this diffusion process is not consistent for men and women, or the messages transmitted are conflictual, this may increase the risk of unintended consequences for indirect beneficiaries. This may be particularly likely if beneficiaries (both men and women) diffuse information differentially when they have participated in an intervention jointly with their spouse, perhaps viewing some parts of the experience as private or shared within the couple.

In this respect, it is interesting to note that the couples' UBL arm was not associated with any diffusion of knowledge on IPV laws to either men or women, while this knowledge diffused successfully to male indirect beneficiaries in the men's UBL arm and to female indirect beneficiaries in the women's UBL arm. Future research should further explore strategies to enhance productive diffusion of information and thus reduce ancillary risks in communities in which IPV interventions are implemented.

Our analysis has several strengths. This trial was explicitly designed to assess spillover effects of UBL, and incorporated a robust double-randomised design in which indirectly exposed individuals are also randomly selected at the outset. A recent systematic review notes that only 2 out of 23 studies estimating within-cluster spillover effects used double-randomised designs. ${ }^{20}$ In the other studies, untreated individuals in treated clusters may have systematically different characteristics from individuals in control characteristics (ie, they were not eligible to receive the intervention, or chose not to participate).$^{20}$

In addition, the analysis systematically compares the relative effectiveness of an IPV intervention delivered to men, women and couples for indirect beneficiaries, and includes data from both male and female spouses. The surveys employed and data collected were identical for respondents who were and were not sampled for the intervention; this allows for direct comparison of primary experimental effects and effects for indirect beneficiaries.

The analysis also has a number of limitations. The most important limitation is that the sample of indirect beneficiaries is small, comprising only $20 \%$ of the baseline sample. In addition, the trial specified multiple outcomes of interest and the analysis of multiple comparisons should accordingly be interpreted with caution in line with existing guidance..$^{334}$

Finally, the analysis relies on measures of IPV that are self-reported, and thus may be subject to social desirability bias. This social desirability bias may be particularly acute for self-reported perpetration of IPV by men, as men who are newly aware of the adverse consequences of IPV may seek to minimise their own engagement in violence, and the difference in intervention effects comparing reported perpetration of IPV by men and reported experience of IPV by women could reflect some potential bias. Importantly, however, the indirect beneficiaries who are the focus of this analysis were not directly exposed to any intervention messaging that might have led them to selectively report perpetration or experience of IPV. In addition, there is no evidence of a decrease in reported perpetration of IPV in the couples' arm, where the intervention similarly directly targeted men, suggesting it is unlikely that social desirability bias alone explains the difference in reported perpetration among indirect beneficiaries in the men's and couples' arms.

\section{CONCLUSION}

In summary, this trial demonstrates the effectiveness of the UBL intervention in reducing reported perpetration of past-year IPV, as well as a range of other outcomes at the broader community-level, beyond households sampled to participate in the programme. These findings suggest that the programme had positive spillover effects in diffusing information, shifting social norms and changing behaviours among indirect beneficiaries within the larger community. Our trial makes unique contributions to the evidence base around diffusion of intervention effects, and has implications for considerations around scale up and cost-effectiveness. 


\section{Author affiliations}

${ }^{1}$ Poverty, Health and Nutrition Division, International Food Policy Research Institute, Washington, District of Columbia, USA

${ }^{2}$ Addis Ababa University School of Public Health, Addis Ababa, Ethiopia

${ }^{3}$ CARE, New York, New York, USA

${ }^{4}$ EngenderHealth, Addis Ababa, Ethiopia

${ }^{5}$ Department of Global Health and Population, Harvard T H Chan School of Public Health, Boston, Massachusetts, USA

Acknowledgements We thank the study participants and communities that participated in this trial, the facilitators that delivered the intervention and the field team who implemented the data collection. We thank Kefyalew Asmara, Nikita Aurora, Arsema Solomon and Muluken Walle for their management of the data collection. We thank Lori Rolleri for her contributions during the intervention development process. We thank the members of the community advisory board for their oversight of the trial and the support we received from partners including the Ethiopian Public Health Association, Addis Ababa University, EngenderHealth, the Ethiopian Ministry of Health, the Ethiopian National HIV/AIDS Prevention and Control Office (HAPCO) as well as the leadership within the study districts at all administrative levels and the village leaders of the study communities. We thank our anonymous donor and the Fondation de France for providing financial support for this trial.

Contributors JL, VS and ND designed the study and oversaw acquisition of data. $\mathrm{JL}$ conducted the statistical analysis. JL and VS drafted the manuscript. FV and ST led the development of the UBL intervention. ST led the facilitator training and intervention implementation. VS, JL and ND contributed to intervention development and implementation. VS, JL, FV, ST and ND were involved in critical revisions of the manuscript for important intellectual content. VS and JL secured funding for the trial. All authors approved the final draft of the manuscript.

Funding This study was funded by Fondation de France and an anonymous donor.

Competing interests VS, FV, ST, ND all received funding for either salary or consulting fees through a grant from an anonymous donor.

\section{Patient consent for publication Not required.}

Ethics approval The study protocol was approved by the Committee on the Use of Humans as Experimental Subjects (COUHES) at MIT (protocol number 1211005333) and by the Institutional Review Board at the AAU College of Health Sciences (protocol number 044/12/SPH). All subjects provided informed oral consent.

Provenance and peer review Not commissioned; externally peer reviewed.

Data availability statement Data are available upon request. The authors will make de-identified data available to scientists planning meta-analyses or to conduct specified and agreed upon further analysis. Requests should be sent to the corresponding author.

Supplemental material This content has been supplied by the author(s). It has not been vetted by BMJ Publishing Group Limited (BMJ) and may not have been peer-reviewed. Any opinions or recommendations discussed are solely those of the author(s) and are not endorsed by BMJ. BMJ disclaims all liability and responsibility arising from any reliance placed on the content. Where the content includes any translated material, BMJ does not warrant the accuracy and reliability of the translations (including but not limited to local regulations, clinical guidelines, terminology, drug names and drug dosages), and is not responsible for any error and/or omissions arising from translation and adaptation or otherwise

Open access This is an open access article distributed in accordance with the Creative Commons Attribution Non Commercial (CC BY-NC 4.0) license, which permits others to distribute, remix, adapt, build upon this work non-commercially, and license their derivative works on different terms, provided the original work is properly cited, appropriate credit is given, any changes made indicated, and the use is non-commercial. See: http://creativecommons.org/licenses/by-nc/4.0/.

\section{ORCID iDs}

Jessica Leight http://orcid.org/0000-0002-1691-9682

Negussie Deyessa http://orcid.org/0000-0002-8843-7287

Vandana Sharma http://orcid.org/0000-0002-4156-0229

\section{REFERENCES}

1 Devries KM, Mak JY, Bacchus LJ, et al. Intimate partner violence and incident depressive symptoms and suicide attempts: a systematic review of longitudinal studies. PLoS Med 2013;10:e1001439.
2 Ellsberg M, Jansen HAFM, Heise L, et al. Intimate partner violence and women's physical and mental health in the WHO multi-country study on women's health and domestic violence: an observational study. The Lancet 2008;371:1165-72.

3 Garcia-Moreno C, Jansen HAFM, Ellsberg M, et al. Prevalence of intimate partner violence: findings from the WHO multi-country study on women's health and domestic violence. The Lancet 2006;368:1260-9.

4 Campbell JC. Health consequences of intimate partner violence. Lancet 2002;359:1331-6.

5 Hill A, Pallitto C, McCleary-Sills J, et al. A systematic review and meta-analysis of intimate partner violence during pregnancy and selected birth outcomes. Int J Gynaecol Obstet 2016;133:269-76.

6 Pronyk PM, Hargreaves JR, Kim JC, et al. Effect of a structural intervention for the prevention of intimate-partner violence and HIV in rural South Africa: a cluster randomised trial. Lancet 2006;368:1973-83

7 Jewkes R, Nduna M, Levin J, et al. Impact of stepping stones on incidence of HIV and HSV-2 and sexual behaviour in rural South Africa: cluster randomised controlled trial. BMJ 2008;337:391-5.

8 Saggurti N, Nair S, Silverman JG, et al. Impact of the RHANI wives intervention on marital conflict and sexual coercion. Int J Gynaecol Obstet 2014:126:18-22.

9 Kapiga S, Harvey S, Mshana G, et al. A social empowerment intervention to prevent intimate partner violence against women in a microfinance scheme in Tanzania: findings from the MAISHA cluster randomised controlled trial. Lancet Glob Health 2019;7:e1423-34.

10 Hossain M, Zimmerman C, Kiss L, et al. Working with men to prevent intimate partner violence in a conflict-affected setting: a pilot cluster randomized controlled trial in rural Côte d'Ivoire. BMC Public Health 2014;14.

11 Vaillant $\mathrm{J}$, Koussoubé $\mathrm{E}$, Roth $\mathrm{D}$, et al. Engaging men to transform inequitable gender attitudes and prevent intimate partner violence: a cluster randomised controlled trial in North and South Kivu, Democratic Republic of Congo. BMJ Glob Health 2020;5:e002223.

12 Doyle K, Levtov RG, Barker G, et al. Gender-transformative Bandebereho couples' intervention to promote male engagement in reproductive and maternal health and violence prevention in Rwanda: findings from a randomized controlled trial. PLoS One 2018;13:e0192756.

13 Gupta J, Falb KL, Lehmann H, et al. Gender norms and economic empowerment intervention to reduce intimate partner violence against women in rural Côte d'Ivoire: a randomized controlled pilot study. BMC Int Health Hum Rights 2013;13:46.

14 Dunkle K, Erin E, Heise L. Impact of Indashyikirwa. An innovative programme to reduce partner violence in rural Rwanda [Internet], 2019. Available: https://www.whatworks.co.za/documents/ publications/352-indash-evidence-brief-aug-2019/file

15 Abramsky T, Devries K, Kiss L, et al. Findings from the Sasa! study: a cluster randomized controlled trial to assess the impact of a community mobilization intervention to prevent violence against women and reduce HIV risk in Kampala, Uganda. BMC Med 2014;12:122.

16 Ogum Alangea D, Addo-Lartey AA, Chirwa ED, et al. Evaluation of the rural response system intervention to prevent violence against women: findings from a community-randomised controlled trial in the central region of Ghana. Glob Health Action 2020;13:1711336.

17 Chatterji S, Stern E, Dunkle K, et al. Community activism as a strategy to reduce intimate partner violence (IPV) in rural Rwanda: results of a community randomised trial. J Glob Health 2020;10:010406.

18 Wagman JA, Gray RH, Campbell JC, et al. Effectiveness of an integrated intimate partner violence and HIV prevention intervention in Rakai, Uganda: analysis of an intervention in an existing cluster randomised cohort. Lancet Glob Health 2015;3:e23-33.

19 Bradley JE, Bhattacharjee P, Ramesh BM, et al. Evaluation of stepping stones as a tool for changing knowledge, attitudes and behaviours associated with gender, relationships and HIV risk in Karnataka, India. BMC Public Health 2011;11:496.

20 Benjamin-Chung J, Abedin J, Berger D, et al. Spillover effects on health outcomes in low- and middle-income countries: a systematic review. Int J Epidemiol 2017;46:1251-76.

21 Benjamin-Chung J, Amin N, Ercumen A, et al. A randomized controlled trial to measure spillover effects of a combined water, sanitation, and handwashing intervention in rural Bangladesh. Am J Epidemiol 2018;187:1733-44.

22 Sharma V, Leight J, Verani F, et al. Effectiveness of a culturally appropriate intervention to prevent intimate partner violence and HIV transmission among men, women, and couples in rural Ethiopia: findings from a cluster-randomized controlled trial. PLoS Med 2020:17:e1003274. 
23 Leight J, Deyessa N, Verani F, et al. An intimate partner violence prevention intervention for men, women, and couples in Ethiopia: additional findings on substance use and depressive symptoms from a cluster-randomized controlled trial. PLoS Med 2020;17:e1003131.

24 Benjamin-Chung J, Arnold BF, Berger D, et al. Spillover effects in epidemiology: parameters, study designs and methodological considerations. Int J Epidemiol 2018;47:332-47.

25 Liang K-YEE, Zeger SL. Longitudinal data analysis using generalized linear models. Biometrika 1986;73:13-22.

26 Starmann E, Heise L, Kyegombe N, et al. Examining diffusion to understand the how of Sasa!, a violence against women and HIV prevention intervention in Uganda. BMC Public Health 2018;18:616.

27 Clemens J, Shin S, Ali M. New approaches to the assessment of vaccine herd protection in clinical trials. Lancet Infect Dis 2011;11:482-7.

28 Cislaghi B, Denny EK, Cissé M, et al. Changing Social Norms: the Importance of "Organized Diffusion" for Scaling Up Community Health Promotion and Women Empowerment Interventions. Prev Sci 2019;20:936-46.
29 Chong A, Gonzalez-Navarro M, Karlan D, et al. Do Information Technologies Improve Teenagers' Sexual Education? Evidence from a Randomized Evaluation in Colombia. World Bank Econ Rev 2020;34:371-92.

30 Dupas P. Do teenagers respond to HIV risk information? Evidence from a field experiment in Kenya. American Economic Journal: Applied Economics 2011;3:1-34.

31 Jaffe J, Kaler A. Coffee ceremonies, gender, and food security in two Ethiopian villages. In: Njuki J, Parkins J, Kaler A, eds. Transforming gender and food security in the global South. New York City: Routledge, 2016: 115-37.

32 Crittenden KS, Kaponda CPN, Jere DL, et al. Participation and diffusion effects of a peer-intervention for HIV prevention among adults in rural Malawi. Soc Sci Med 2015;133:136-44.

33 Moher D, Hopewell S, Schulz KF, et al. Consort 2010 explanation and elaboration: updated guidelines for reporting parallel group randomised trials. Int J Surg 2012;10:28-55.

34 Rothman KJ. No adjustments are needed for multiple comparisons. Epidemiology 1990;1:43-6. 